\title{
Determining Force behind Value Premium: The Case of Financial Leverage and Operating Leverage
}

\author{
Hafiz Muhammad Zia ul haq ${ }^{1, *(D)}$, Muhammad Sohail Shafiq ${ }^{1}$, Muhammad Kashif ${ }^{2}$ \\ and Saba Ameer 1,3 \\ 1 Faculty of Business Economics and Social Development, University Malaysia Terengganu, \\ Kuala Nerus 21030, Terengganu, Malaysia; sohailch.715@gmail.com (M.S.S.); saba@vcomsats.edu.pk (S.A.) \\ 2 Nord University Business School, Nord University, Universitetsalléen 11, 8026 Bodø, Norway; \\ muhammad.kashif@nord.no \\ 3 Department of Management Sciences, COMSATS University, Islamabad 45550, Pakistan \\ * Correspondence: muhammad_ziaulhaq@hotmail.com
}

Received: 27 July 2020; Accepted: 31 August 2020; Published: 2 September 2020

\begin{abstract}
The determining force behind the value premium is the matter of debate among the researchers. Some are of the opinion that the financial distress risk determines value premium whereas other theorize that value premium is basically the compensation for operating leverage (investment activity risk). This research provides empirical evidence on this theoretical contradiction by investigating the relationships of financial leverage (FL) and operating leverage (OL) with stock returns, the book to market ratio (B/M), and systematic risk on non-financial sector firms trading at the Pakistan stock exchange (PSE). This research empirically finds significant and direct influence of operating leverage on stock returns, the book to market ratio, and systematic risk respectively. Overall findings provide support for the theoretical models which have a linked book to market effect with operating leverage. Thus, we conclude that investment activity risk seems to be the major factor that determines value premium.
\end{abstract}

Keywords: value premium; stock returns; operating leverage; systematic risk ( $\beta$ ); financial leverage

\section{Introduction}

The association between systematic risk $(\beta)$ and stock return remains a matter of interest among researchers, mainly because of its significant role in academics as well as in real-world applications. The capital asset pricing model (CAPM) developed by Sharpe (1964), is the most popular and commonly used asset pricing model that explains the relationship of stock return with systematic risk. Various authors (Fama and French 1992, 1996, 2015; Hou et al. 2015; Light et al. 2017; McLean and Pontiff 2016) have extended and generalized the CAPM. Basically, CAPM states that systematic risk is the only factor that has a significant linear relationship with stock return. However, many researchers contradicted this opinion as they find various other variables explaining stock returns. Firm size and book to market ratio $(\mathrm{B} / \mathrm{M})$ are the two important factors found in the literature (Fama and French 1992) that significantly affect firm's stock return. Fama and French (1992) identify a B/M effect by indicating that firm stocks with a higher $\mathrm{B} / \mathrm{M}$ ratio experience greater returns compared to firm stocks with a lower $\mathrm{B} / \mathrm{M}$ ratio. This relationship of a high $\mathrm{B} / \mathrm{M}$ ratio and high stock return is also known as the value effect as such stocks with fewer market prices and poor past performance are usually referred to as value stocks. It can be described in the way that value (high $\mathrm{B} / \mathrm{M}$ ) stocks have greater returns compared to the growth (low B/M) stocks (Guthrie 2013; Fong 2012).

Lack of strong theoretical explanation on value premium has remained a matter of great concern among researchers. Many researchers have given contradictory theoretical opinions on value premium. 
Some (Lakonishok et al. 1994; Daniel and Titman 1997) suggest value premium as the compensation for mispricing due to behavioral differences whereas others (Fama and French 1993,1996) argue that it reflects compensation for systematic risk. Additionally, the researchers have also conflicted on the kind of systematic risk causing value premium, whether it reflects risk of financial distress or risk of investment activity. Some researchers (Chen and Zhang 1998; Fama and French 1995; Ozdagli 2012; Obreja 2013) are of the opinion that firm stocks with a higher B/M ratio face higher levels of distress risk, thus experiencing higher stock returns. They indicate that firms with a higher $\mathrm{B} / \mathrm{M}$ ratio face uncertain and fewer earnings with a higher degree of financial leverage (DFL); therefore, such firms are more probable to reduce their dividends compared to their counter firms with a lesser $\mathrm{B} / \mathrm{M}$ ratio.

Contrary to this, a number of recent theoretical models (Gulen et al. 2011; Zhang 2005; Carlson et al. 2004; Berk et al. 1999) have evolved that link variation in expected stock returns with risk relating to a firm's investment decisions. These models state that value or high B/M stocks face greater systematic risk due to a high degree of operating leverage (DOL), thus earn higher stock returns. In fact, these studies have also reported a direct relationship between $\mathrm{B} / \mathrm{M}$ and DOL, suggesting operating leverage as the major factor behind systematic risk that causes a book to market effect or value premium. This theoretical literature argues that investment decisions are normally analyzed on the basis of real options context and options exercised can cause variations in the firm's systematic risk. For instance, if growth opportunities are limited then a firm's investment decision causes nominal change in the growth option to asset ratio. In addition to this, it also results in increasing physical capital which further causes operating leverage to increase through long term obligations, such as commitments to suppliers, wage contracts, and fixed costs. So, these studies conclude that high B/M firms face a higher level of risk due to investment decisions, and hence, earn higher returns compared to low $\mathrm{B} / \mathrm{M}$ firms.

Considering this theoretical debate, it implies that there is lack of conclusive evidence on the determining factor of value premium. Recently, few studies have empirically examined the issue but still reported evidence which is contradictory and inconclusive. For instance, García-Feijóo and Jorgensen (2010) report a direct and significant association of operating leverage with value premium while Cao (2015) provides evidence in support of financial leverage. Given the diverse theoretical opinions regarding the determining factor of value premium, there is a strong need to empirically examine both opinions with an aim to provide better implications for investors and firms. Therefore, this research analyzes the effect of both type of leverages i.e., financial and operating, on firm's stock returns, systematic risk, and B/M ratio in order to provide beneficial findings on the concerned problem.

In the case of Pakistan, a number of studies (Iqbal and Brooks 2007; Javid and Ahmed 2008; Javid 2009) have the analyzed capital asset pricing model (CAPM), and report that traditional CAPM is invalid in the context of the Pakistan stock market. Recently, Wu et al. (2017) also test single factor CAPM and report invalidity in the Pakistan stock market. However, literature reports a significant effect of firm size and B/M ratio on stock returns. Similarly, few studies (Khan et al. 2012; Mirza and Shahid 2008) have also examined Fama and French's three factor model and report significant evidence for both size and value effects. Additionally, empirical evidence on the existence of value premium is also examined and reported in the existing literature (Shah and Amir 2017; Hassan and Javed 2011). Although studies have tested different asset pricing models, still there is a great need to investigate the new dimensions of the asset pricing and value premium issue. In addition to this, there is a lack of empirical evidence on the factors determining value premium. Considering this, our research is an effort to fill the gap in the literature and provides empirical evidence on the determining factors of value premium in the context of the Pakistan stock exchange.

This paper contributes by reporting direct empirical evidence from the Pakistan stock exchange (PSE) for both theoretical opinions relating to determining cause of value premium that whether it is determined by investment activity risk (operating leverage) or financial distress risk (financial leverage). This paper also contributes by exploring a number of important factors explaining stock returns in 
the context of the Pakistan Stock Exchange (PSE), allowing generalization for other less developed financial markets.

\section{Hypothesis Development}

\subsection{Operating Leverage and Value Premium}

There are number of studies (Mandelker and Rhee 1984; Lev 1974; Hamada 1972; Rubinstein 1973) that provide a theoretical base regarding the effect of DFL and DOL on a firm's systematic risk. This theoretical literature suggests direct association between firms' operating leverage and systematic risk. Carlson et al. (2004) state that systematic risk has a particular proportion that is derived from operating leverage. According to their argument, the $\mathrm{B} / \mathrm{M}$ ratio represents this particular operating leverage component of systematic risk. In addition to Carlson et al. (2004), some other theoretical models (Berk et al. 1999; Zhang 2005) also explain operating leverage as major determining factor of value premium. These studies argue that risk of investment activity is the kind of systematic risk that determines value premium. According to their opinion, investment decisions are normally analyzed on the basis of real options' context, and option exercised can cause firm risk to vary in different aspects; suppose if there are fewer growth opportunities, due to which change in investment decisions causes the growth option to asset ratio to change as well. In addition to this, it also results in an increase in physical capital which further causes the operating leverage to increase through long term obligations, for example commitments to suppliers, wage contracts, and fixed costs. Therefore, these studies (Zhang 2005; Carlson et al. 2004; Berk et al. 1999) suggest that firms with a higher $\mathrm{B} / \mathrm{M}$ ratio face higher risk due to investment decisions, thus these firms make more returns relative to their counter firms with a low $\mathrm{B} / \mathrm{M}$ ratio.

Similarly, Novy-Marx (2011) reasons that within operating leverage, it is specifically an operating cost component that causes value premium, thus implying that value premium is expected to be high in the firms with higher operating costs. As far as empirical evidence is concerned, there are very few studies (Novy-Marx 2011; Cao 2015; García-Feijóo and Jorgensen 2010), which have examined association between operating leverage and value effect. However, these studies also exhibit mixed results. For instance, Novy-Marx (2011) and Cao (2015) report insignificant association between the operating leverage and value effect. Conversely, García-Feijóo and Jorgensen (2010) and Gulen et al. (2011) provide strong evidence supporting the positive association of operating leverage with value premium as suggested by the above theoretical models (Berk et al. 1999; Zhang 2005; Carlson et al. 2004). Therefore, it is crucial to analyze the causal effect of operating leverage on value premium. Considering arguments from the above-mentioned theoretical models, this study also hypothesizes operating leverage as major determinant of value premium based on its positive hypothesized effects on stock returns, B/M ratio, and market risk.

Hypothesis 1. Operating leverage determines value premium.

\subsection{Financial Leverage and Value Premium}

Financial leverage has also been considered as a potential determinant of systematic risk since the time of Modigliani and Miller $(1958,1963)$, Bowman (1979) and Hamada (1972), but the empirical evidence of direct association between two remains inconsistent. Modigliani and Miller (1963) theorizes a positive relationship of financial leverage with firm value because of tax deductibility of financial payments. Considering Modigliani and Miller' theorem, Ozdagli (2012) argues that financial leverage is positively related with value premium because of its association with systemic risk and firm value. Mandelker and Rhee (1984) prove a direct relationship between DFL and beta while Lord (1996) and Darrat and Mukherjee (1995) report no relationship between the two. In addition to this, Huffman (1983) reports a tradeoff relation among financial leverage and operating leverage, which also suggests role of DFL as a control variable in this study. 
Furthermore, Fama and French (1996) claim that value effect is basically reward for the financial distress risk. As financial distress risk is highly correlated with DFL, so variable DFL can also be used to shed some light regarding the relationship of financial distress risk and value premium. Recently, models developed by Obreja (2013) and Ozdagli (2012) state that financial leverage has the primary role in generating value premium. According to Ozdagli (2012), there is not much variation in operating leverage across the value spectrum; therefore, operating leverage cannot explain the value premium. Hence, Ozdagli (2012) argues that financial leverage has an association with systematic risk due to which it influences value premium.

In addition to this, Obreja (2013) argues that the determining force behind value premium depends on fixed production costs of the firm. According to the model developed by Obreja (2013), in the firms with higher level of fixed costs, value effect or $\mathrm{B} / \mathrm{M}$ effect is determined by operating leverage while in the firms with lower fixed costs, it is financial leverage that determines the value premium. However, empirically, literature has shown inconclusive evidence regarding the relationship of financial leverage with the value effect. For instance, Cao (2015) reports evidence in favor of Ozdagli (2012) and Obreja (2013)'s models which hypothesize the positive relationship of financial leverage with the value effect. On the other hand, García-Feijóo and Jorgensen (2010) and Campbell et al. (2008) report that value premium is not related with financial distress risk or financial leverage. Therefore, this study also aims to provide empirical evidence on the relationship of financial leverage with value premium. Considering theoretical arguments, we hypothesize the determining impact of financial leverage on value premium based on its positive relationship with stock returns, B/M ratio, and firm's market risk.

Hypothesis 2. Financial leverage determines value premium.

\section{Research Method}

\subsection{Data}

The sample consists of 84 firms belonging to the non-financial sector, listed at the PSE. This study has excluded financial firms because of their dissimilar nature in terms of capital structure and accounting period. We also excluded the firms which have negative DFL because an economically negative value for DFL is irrational. The sample covers period from 2005 to 2017 with 84 non-financial firms. The monthly data which includes stock prices, monthly returns, and number of shares outstanding have been collected from data sources of the PSE and Business recorder. Whereas, data on financial statements are collected from annual reports of the firms and State bank of Pakistan. These data relating to financial statements include sales, administrative, selling and general expenses (SGA), cost of goods sold (COGS), interest expenses, earnings before interest and taxes (EBIT), total assets, total common equity, and earnings after interest and taxes (EAIT). Then, by using these data, different firm-specific variables are calculated and used in the empirical models of this research.

\subsection{Variable Measurement}

This section includes the explanation and computation of all variables used in this research. A number of proxies are used to measure major variables. The construction of these variables is presented in this section.

\subsubsection{Stock Returns, Firm Size, and B/M Ratio}

Annual stock returns of the firm $(\mathrm{R})$ are measured by taking a natural logarithm of stock's market price in period $t$ divided by the stock's market price in period $t-1$. The size of the firm is represented by Market equity or capitalization (ME), which is measured by multiplying the market price of the stock and the number of stocks outstanding at the end of each June. Another very important variable 
$\mathrm{B} / \mathrm{M}$ ratio is computed as the book price of stock divided by market price of stock. This $\mathrm{B} / \mathrm{M}$ value is used as proxy for the value premium effect.

$$
\begin{gathered}
R_{i}=\operatorname{Ln}\left(\frac{p_{t}}{p_{t-1}}\right) \\
\text { Size }(M E)=\text { Marketprice of share } \times \text { Total number of shares outstanding } \\
\frac{B}{M} \text { ratio }=\frac{\text { Book price of share }}{\text { Market price of share }}
\end{gathered}
$$

\subsubsection{Degree of Operating Leverage and Degree of Financial Leverage}

We use the regression method given by the Mandelker and Rhee (1984) for estimating our major explanatory variables i.e., financial leverage and operating leverage represented by DFL and DOL, respectively. This method of Mandelker and Rhee (1984) has one drawback that estimates for DOL and DFL obtained by this approach can be time invariant. So, to deal with this problem, this study has used the empirical approach given by García-Feijóo and Jorgensen (2010), which suggest time varying estimates to be obtained by estimating regressions at three years overlapping intervals.

So, for the estimation of DOL and DFL, following regressions have been used in this research:

$$
\begin{aligned}
& \operatorname{lnEBIT_{t}}=\text { DOLlnSales }_{t}+u_{t} \\
& \operatorname{lnEAIT}_{t}=\boldsymbol{D F L} \ln E B I T_{t}+u_{t}
\end{aligned}
$$

where $E B I T_{t}, E A I T_{t}$, and Sales $t_{t}$ are the operating income, net income, and sales for the period $t$, respectively. Firstly, for the estimating DOL, $\operatorname{lnEBIT}$ is regressed on $\ln$ Sales and the coefficient estimated is used as the value of DOL for period $t$. Similarly, lnEAIT is regressed on lnEBIT and the coefficient estimated is used as the value of DFL for period $t$. Here, DOL shows the average degree of change in EBIT (operating income) relative to change in Sales, and DFL shows the sensitivity of change in EAIT (net income) relative to change in EBIT (operating income). We have used three year's overlapping regression approach following García-Feijóo and Jorgensen (2010), to obtain the annual values of DOL and DFL. In order to compute logs of negative earnings, we have used the transformation technique given by Ljungqvist and Wilhelm (2005), according to which:

$$
\operatorname{Ln}(1+\text { earnings }) \text { if earnings } \geq 0 \text { and }-\operatorname{Ln}(1 \text { - earnings }) \text { if earnings } \leq 0
$$

\subsubsection{Systematic Risk (Beta)}

Levered beta (equity beta) is used in order to compute value for systematic risk, as it captures the effect of capital structure. This is the reason it is more appropriate for this research, as we are concerned in the roles of both DFL and DOL in determining systematic risk. The other measure of market risk is unlevered beta (asset beta) which gives systematic risk irrespective of the capital structure nature. We use the most common market model for the estimation of systematic risk beta following the Fama and MacBeth (1973) rolling regression technique.

$$
R_{i t}=\alpha_{i t}+\beta_{i t} R_{m t}
$$

in which, $R_{i t}$ (return of firm stock $i$ in time period $t$ ) is regressed on $R_{m t}$ (return on value weighted market portfolio), and estimated $\beta_{i t}$ is used as the systematic risk. Here, we also use three-year overlapping regression approach similar to the estimation of DOL and DFL. 


\subsubsection{Alternative Measures for Robustness}

Alternative proxies of both dependent and independent variables are also used in this research for robustness. Average monthly stock return is used as an alternative variable for a dependent variable i.e., stock return of the firm. This alternative variable (R01) for each firm, is calculated by taking an average of each firm's monthly stock returns. Average monthly stock return is also used by García-Feijóo and Jorgensen (2010) for examining the relationship of stock returns with DOL and DFL.

Additionally, for the accuracy of results, we also use alternative proxies for the two major independent variables which are both leverages. These alternative proxies have been used to compare the results with major findings. This study uses the DFL01 and DOL01 as alternative variables measuring financial leverage and operating leverage. These alternative proxies are calculated using a point-to-point approach following Novy-Marx (2011). Here, DFL is calculated directly from the financial statements by dividing EBIT with difference of EBIT and interest. Whereas DOL is calculated as by dividing sum of SGA and COGS with total assets.

$$
\begin{aligned}
& \text { DFL01 }=\frac{E B I T}{\text { EBIT }- \text { interest }} \\
& \text { DOL01 }=\frac{\text { COGS }+S G A}{T A}
\end{aligned}
$$

\subsubsection{Control Variables}

Lastly, we also include three control variables in the model other than size. These control variables include earning per share (EPS), sale growth (SG), and price over earnings ratio (P/E). The purpose of using control variables in the analysis is to avoid omitted variable biasness and to achieve more accurate results. These have been calculated for each firm by the given formulas: $S G$ is calculated by measuring the increase in sales of two consecutive years. EPS is measured by dividing EAIT (net income) with total number of shares. $\mathrm{P} / \mathrm{E}$ is computed as market price of each stock divided by earning per each stock.

$$
\begin{gathered}
\text { Sale growth }(\mathrm{sg})=\frac{\text { sale }_{t}-\text { sale }_{0}}{\text { sale }_{0}} \\
\text { Earning per share }(E P S)=\frac{\text { Net income }}{\text { Total number of shares }} \\
\frac{P}{E} \text { ratio }=\frac{\text { Market price of share }}{\text { Earning per share }}
\end{gathered}
$$

\subsection{Empirical Design and Estimation Technique}

In order to provide empirical evidence on hypothesized theoretical relationships regarding DOL and DFL, we apply a multivariate regression method involving panel data analysis. Various models have been constructed and used in different structures to analyze objectives of this research. The following three main empirical models have been estimated in different forms.

\subsubsection{Stock Return as Dependent Variable}

(i) In the first model, individual stock returns $\left(R_{i t}\right)$ are regressed on operating leverage $\left(D O L_{i t}\right)$, financial leverage $\left(D F L_{i t}\right)$, market capitalization $\left(M E_{i t}\right)$, systematic risk $\left(\beta_{i t}\right)$, sale growth $\left(S G_{i t}\right)$, price to earnings ratio $\left(P / E_{i t}\right)$, and earning per share $\left(E P S_{i t}\right)$. This model has been used to find significant factors affecting the returns on the firm's stocks. Specifically, the purpose is to analyze the hypothesized relationship of stock returns with the DOL, DFL, and systematic risk.

$$
R_{i t}=\alpha_{0}+\alpha_{1} D O L_{i t}+\alpha_{2} D F L_{i t}+\alpha_{3} M E_{i t}+\alpha_{4} \beta_{i t}+\alpha_{5} S G_{i t}+\alpha_{6} P / E_{i t}+\alpha_{7} E P S_{i t}+u_{i t}
$$


(ii) For the robustness, we also use second structure of this model in which alternative variables for stock returns are used. In this version of the model, average monthly stock returns are used as dependent variable and these average monthly stock returns $\left(R 01_{i t}\right)$ are regressed on the same independent variables from the first structure which includes operating leverage $\left(D O L_{i t}\right)$, financial leverage $\left(D F L_{i t}\right)$, market capitalization $\left(M E_{i t}\right)$, systematic risk $\left(\beta_{i t}\right)$, sale growth $\left(S G_{i t}\right)$, price to earnings ratio $\left(P / E_{i t}\right)$, and earning per share $\left(E P S_{i t}\right)$.

$$
R 01_{i t}=\alpha_{0}+\alpha_{1} D O L_{i t}+\alpha_{2} D F L_{i t}+\alpha_{3} M E_{i t}+\alpha_{4} \beta_{i t}+\alpha_{5} S G_{i t}+\alpha_{6} P / E_{i t}+\alpha_{7} E P S_{i t}+u_{i t}
$$

(iii) Then, in the third phase, alternative variables for DOL and DFL are used. In this structure, annual stock returns $\left(R_{i t}\right)$ are regressed on the same independent variables but with alternative point-to-point measures of both leverages which are $\left(D O L 01_{i t}\right)$ and $\left(D F L 01_{i t}\right)$.

$$
R_{i t}=\alpha_{0}+\alpha_{1} D O L 01_{i t}+\alpha_{2} D F L 01_{i t}+\alpha_{3} M E_{i t}+\alpha_{4} \beta_{i t}+\alpha_{5} S G_{i t}+\alpha_{6} P / E_{i t}+\alpha_{7} E P S_{i t}+u_{i t}
$$

(iv) In the last structure, a model is estimated using alternative proxies of both dependent and independent variables. Here, average of monthly stock returns $\left(R 01_{i t}\right)$ are regressed on point-to-point measures of operating $\left(D O L 01_{i t}\right)$ and financial $\left(D F L 01_{i t}\right)$ leverages along with other independent variables.

$$
R 01_{i t}=\alpha_{0}+\alpha_{1} D O L 01_{i t}+\alpha_{2} D_{F L 01}+\alpha_{3} M E_{i t}+\alpha_{4} \beta_{i t}+\alpha_{5} S G_{i t}+\alpha_{6} P / E_{i t}+\alpha_{7} E P S_{i t}+u_{i t}
$$

\subsubsection{Book to Market Ratio as Dependent Variable}

Then second model is estimated to analyze the relationship of operating and financial leverages with the value effect (B/M ratio). The findings from this model also help us to clarify our main objective that whether the value effect provides compensation for investment activity risk or it is the compensation of financial distress risk. In this model $\mathrm{B} / \mathrm{M}$ ratio is used as a dependent variable and it is regressed on both DOL and DFL.

$$
\left(\frac{B E}{M E}\right)_{i t}=\alpha_{0}+\alpha_{1} D O L_{i t}+\alpha_{2} D F L_{i t}+u_{i t}
$$

For robust testing, we also use alternative point-to-point measures of DOL and DFL. So, these structures using both type of measurements are used to examine the hypothesized relationship of the $\mathrm{B} / \mathrm{M}$ ratio with both type of leverages.

$$
\left(\frac{B E}{M E}\right)_{i t}=\alpha_{0}+\alpha_{1} D O L 01_{i t}+\alpha_{2} D F L 01_{i t}+u_{i t}
$$

\subsubsection{Systematic Risk of Portfolios as a Dependent Variable}

Lastly, the third model is regressed to analyze the relationship of operating and financial leverages with systematic risk (beta). In this model, a portfolio grouping approach is used, firms have been sorted based on the leverage, and then portfolios are formed by grouping together every four firms from the rank order. Then, by taking averages of each portfolio, systematic risk $\left(\beta_{p}\right)$, operating leverage $\left(D O L_{p}\right)$, financial leverage $\left(D F L_{p}\right)$, and firm size $\left(M E_{p}\right)$ are calculated for each portfolio. This approach of portfolio regressions is taken from Mandelker and Rhee (1984) for examining the relationship of Beta with DOL and DFL, respectively. So, after forming portfolios and variable computation, data for twenty portfolios are used for the portfolio regression analysis. In this model $\beta_{p}$ is regressed on $D O L_{p}$ and $D F L_{p}$ separately with $M E_{p}$ to examine association between market risk and both leverages, respectively. The variable, portfolio market capitalization is included as control variable.

$$
\beta_{p}=\alpha_{0}+\alpha_{1} D O L_{p}+\alpha_{2} D F L_{p}+\alpha_{3} M E_{p}+u_{p}
$$




\subsubsection{Estimation Techniques}

In order to estimate the models, the ordinary least square (OLS) estimation technique is applied based on panel unit root testing. We use the Levin et al. (2002) test to perform panel unit root testing. The results show stationarity at level for all variables, which is one of the conditions to use the OLS technique. The Hausman test (Hausman 1978) is used to examine whether the random effect method is better or the fixed effect method. It is actually used to explore the goodness of random effect where the fixed effect is already appropriate. The larger value for the Hausman test favors the fixed effect method and the smaller value implies appropriation of the random effect method. In addition to this, we also apply panel corrected standard errors (PCSE) in estimation of all regression models to tackle problems of heteroscedasticity and autocorrelation.

\section{Results and Discussion}

\subsection{Descriptive Analysis}

Table 1 reports results on the statistical behavior of the data. Descriptive analysis presents five summary statistics which are mean, median, standard deviation, minimum, and maximum values for both firm variables as well as portfolio variables. Natural log of variables is used for the purpose of data smoothening, whereas stock return and systematic risk are used in real form.

Table 1. Descriptive Statistics.

\begin{tabular}{cccccc}
\hline Variables & Mean & Median & Maximum & Minimum & Std. Deviation \\
\hline$R$ & 0.0475 & 0.0081 & 2.2892 & -1.9196 & 0.5926 \\
Beta $(\beta)$ & 0.622 & 0.6389 & 6.0704 & -3.265 & 0.6812 \\
LnDOL & 0.8497 & 0.3934 & 8.8445 & -5.5825 & 2.0657 \\
LnDFL & -0.3958 & -0.3876 & 4.6303 & -63.9016 & 3.4128 \\
LnME & 20.7717 & 20.8678 & 26.533 & 14.691 & 2.3291 \\
LnB/M & -0.9966 & -1.1709 & 3.6497 & -4.372 & 1.5613 \\
LnSG & 0.4844 & 0.4837 & 2.8848 & -0.6931 & 0.2568 \\
LnEPS & 5.0667 & 5.0524 & 5.9245 & -2.9135 & 0.2963 \\
LnP/E & 7.3726 & 7.3716 & 9.6478 & 1.0629 & 0.2488 \\
Beta $\left(\beta_{p}\right)$ & 0.9545 & 0.9649 & 1.3762 & -0.2007 & 0.1578 \\
LnDOL & 1.6985 & 1.351 & 7.4606 & -1.406 & 1.7733 \\
LnDFL & 0.3557 & -0.0199 & 3.3242 & -2.4058 & 1.2151 \\
LnME & 20.7194 & 20.6828 & 23.4024 & 16.5327 & 1.5443 \\
\hline
\end{tabular}

In Table 2, part (i) and part (ii) present correlation matrices for firm specific variables and portfolio variables, respectively. Results reveal that correlation values among all different independent variables are less than 0.8 , which indicates a lack of strong correlation and absence of a multicollinearity problem. This leads to the suitability of the ordinary least square estimation technique for measuring multivariate regression models.

Furthermore, we also apply panel unit root testing for the selection of estimation technique. Panel unit root testing confirms stationarity of all variables used in this research, which support application of the OLS technique for the estimating results. The estimates of panel unit root test (Levin et al. 2002) are presented in Table 3, where all probability values are less than 0.05 , which clearly shows that all variables included in both firm level and portfolio regression analysis are stationary at level, thus justifying the use of the OLS technique for the estimation of multivariate panel regression models. 
Table 2. (i): Correlation between firm specific variables. (ii): Correlation between portfolio variables.

\begin{tabular}{|c|c|c|c|c|c|c|c|c|c|}
\hline \multicolumn{10}{|c|}{ (i) } \\
\hline & $R$ & BETA $(\beta)$ & LNDOL & LNDFL & LNME & $L N B / M$ & LNSG & LNEPS & $L N P / E$ \\
\hline$R$ & 1 & & & & & & & & \\
\hline $\operatorname{BETA}(\beta)$ & 0.0844 & 1 & & & & & & & \\
\hline LNDOL & -0.0226 & 0.0028 & 1 & & & & & & \\
\hline LNDFL & 0.0123 & -0.0228 & -0.069 & 1 & & & & & \\
\hline LNME & 0.122 & 0.2127 & -0.2552 & 0.1147 & 1 & & & & \\
\hline$L N B / M$ & -0.2352 & -0.1003 & 0.3698 & -0.1096 & -0.7837 & 1 & & & \\
\hline LNSG & 0.0422 & 0.0551 & -0.1104 & -0.0138 & 0.0601 & -0.0372 & 1 & & \\
\hline LNEPS & 0.0747 & 0.0776 & -0.1343 & 0.0188 & 0.2662 & -0.3072 & 0.1317 & 1 & \\
\hline$L N P / E$ & 0.0544 & 0.0294 & 0.0231 & -0.1055 & -0.0269 & -0.0097 & -0.0021 & 0.0041 & 1 \\
\hline \multicolumn{10}{|c|}{ (ii) } \\
\hline & $L N \beta_{p}$ & $L N D P L_{p}$ & $L_{N D F L_{p}}$ & $L N M E_{p}$ & & & & & \\
\hline$\beta_{p}$ & 1 & & & & & & & & \\
\hline$L N D O L_{p}$ & -0.1010 & 1 & & & & & & & \\
\hline$L_{N D F L_{p}}$ & -0.1237 & -0.0665 & 1 & & & & & & \\
\hline$L N M E_{p}$ & 0.3503 & -0.4669 & -0.0317 & 1 & & & & & \\
\hline
\end{tabular}

Table 3. Unit Root Test Results.

\begin{tabular}{ccc}
\hline Variables & LL Statistics & Probability \\
\hline$R$ & -7.89744 & 0.0000 \\
BETA $(\beta)$ & -14.7809 & 0.0000 \\
LNDOL & -15.1770 & 0.0000 \\
LNDFL & -23.6754 & 0.0000 \\
$L N M E$ & -15.6739 & 0.0000 \\
$L N B / M$ & -10.9962 & 0.0000 \\
$L N S G$ & -10.0328 & 0.0000 \\
$L N E P S$ & -3.87257 & 0.0001 \\
$L N P / E$ & -21.8929 & 0.0000 \\
Beta $\left(\beta_{p}\right)$ & -8.13816 & 0.0000 \\
$L N D O L_{p}$ & -4.56870 & 0.0000 \\
$L N D F L_{p}$ & -15.9684 & 0.0000 \\
$L N M E_{p}$ & -6.44407 & 0.0000 \\
\hline
\end{tabular}

\subsection{Multivariate Regression Analysis}

In a panel regression analysis, firstly we estimate an empirical model for examining the relationship of stock returns with DOL, DFL, systematic risk ( $\beta$ ), and size (ME) by controlling sale growth (SG), $\mathrm{P} / \mathrm{E}$ ratio, and EPS. The estimates obtained on stock return regressions are reported in Table 4, where coefficients and t-statistics indicate direction and strength of the estimates. Results reported in the first column of Table 4, reveal that DOL is found directly influencing stock returns at $5 \%$ significant level. Firm size (ME) and systematic risk $(\beta)$ are also found positively associated with stock returns at $1 \%$ and $10 \%$ levels of significance, respectively, while DFL is found insignificantly influencing stock returns. These findings provide support to the theoretical models which suggest a positive association of operating leverage with stock returns. In addition to this, these findings also provide support to the theoretical association of beta with stock returns. Similarly, our findings are also consistent with the existing empirical literature, which state that beta is not the only variable influencing stock returns, as coefficients of DOL and size (ME) are also found positive and significant. We also verify our results by estimating same regression model using alternate variable measurement for dependent, which is average monthly stock returns (R01). Estimates reported in the third column of Table 4, show that DOL is again found directly influencing stock returns at $5 \%$ significance level. Similarly, firm size (ME) is also found to have positive influence on stock returns at $1 \%$ significance level. On the other hand, results again show that DFL is not significantly related with stock returns. 
Table 4. Multivariate regression results.

\begin{tabular}{|c|c|c|c|c|}
\hline \multirow[b]{2}{*}{ Intercept } & \multicolumn{2}{|c|}{ Annual Stock Returns } & \multicolumn{2}{|c|}{ Average Monthly Stock Returns } \\
\hline & $\begin{array}{c}-8.09^{* * *} \\
(-4.46)\end{array}$ & $\begin{array}{l}-4.8 \text { ** } \\
(-2.01)\end{array}$ & $\begin{array}{c}-0.63^{* * *} \\
(-4.23)\end{array}$ & $\begin{array}{l}-0.25 * \\
(-1.77)\end{array}$ \\
\hline $\operatorname{BETA}(\beta)$ & $\begin{array}{l}0.09 * \\
(1.66)\end{array}$ & $\begin{array}{l}0.10 * \\
(1.68)\end{array}$ & $\begin{array}{l}0.005 \\
(1.30)\end{array}$ & $\begin{array}{c}0.008 \text { ** } \\
(2.53)\end{array}$ \\
\hline LNDOL & $\begin{array}{l}0.02 \text { ** } \\
(2.31)\end{array}$ & & $\begin{array}{l}0.002 * * \\
(-2.09)\end{array}$ & \\
\hline LNDFL & $\begin{array}{l}0.006 \\
(1.12)\end{array}$ & & $\begin{array}{c}0.0006 \\
(1.18)\end{array}$ & \\
\hline$L N D O L_{01}$ & & $\begin{array}{c}0.13^{* * *} \\
(2.99)\end{array}$ & & $\begin{array}{c}0.01^{* * *} \\
(2.67)\end{array}$ \\
\hline$L_{N D F L_{01}}$ & & $\begin{array}{c}-0.02 \\
(-0.21)\end{array}$ & & $\begin{array}{l}-0.03 * \\
(-1.90)\end{array}$ \\
\hline LNME & $\begin{array}{c}0.37^{* * * *} \\
(4.46)\end{array}$ & $\begin{array}{l}0.18^{*} \\
(1.69)\end{array}$ & $\begin{array}{c}0.028^{* * *} \\
(4.23)\end{array}$ & $\begin{array}{c}0.012^{* * * *} \\
(5.03)\end{array}$ \\
\hline LNSG & $\begin{array}{l}0.10 \\
(1.3)\end{array}$ & $\begin{array}{l}-0.004 \\
(-0.04)\end{array}$ & $\begin{array}{l}0.008 \\
(1.20)\end{array}$ & $\begin{array}{c}0.0005 \\
(-0.008)\end{array}$ \\
\hline LNEPS & $\begin{array}{c}0.04 \\
(0.30)\end{array}$ & $\begin{array}{c}0.12 \\
(0.67)\end{array}$ & $\begin{array}{l}0.006 \\
(0.55)\end{array}$ & $\begin{array}{c}0.014 \\
(0.626)\end{array}$ \\
\hline$L N P E$ & $\begin{array}{l}0.009 \\
(0.10)\end{array}$ & $\begin{array}{c}0.09 \\
(0.820)\end{array}$ & $\begin{array}{c}0.001 \\
(0.104)\end{array}$ & $\begin{array}{l}0.007 \\
(1.08)\end{array}$ \\
\hline Adj-R square & 0.45 & 0.12 & 0.44 & 0.11 \\
\hline
\end{tabular}

Notes: This table examines the results from regressing firm stock returns on firm degree of operating leverage, degree of financial leverage and control variables. Values of $\mathrm{t}$-statistics are shown in the parentheses. $* * * * *$, and $*$ indicate the coefficient is significant at $1 \%, 5 \%$, and $10 \%$, respectively.

Furthermore, we also test robustness using alternative proxies of major explanatory variables that are both financial and operating leverages. Stock return models are estimated again incorporating point-to-point measures (lnDOL01 and lnDFL01) of operating and financial leverages. The results of these alternative variable regressions are given in second and fourth columns of Table 4. First of all, annual stock returns $(\mathrm{R})$ are regressed on alternative proxies DOL01 and DFL01 along with other independent variables; in this structure, coefficient of DOL01 is found positive and highly significant ( $1 \%$ level) whereas systematic risk ( $\beta$ ) and size (ME) are found positively related with stock returns at $10 \%$ level of significance. However, DFL01 is again found insignificantly negatively influencing stock returns. In the last, alternative measurements of both explained and explanatory variables are also used in the same model where average monthly stock returns (R01) are regressed on alternative proxies of operating and financial leverages (DOL01 and DFL01) along with other independent variables. In this structure, we found more significant effects;: firstly, DOL01 and firm size (ME) are found directly affecting stock returns at $1 \%$ significance level; secondly, systematic risk $(\beta)$ is also found to have significant direct influence on stock returns at $5 \%$. On the other hand, this time DFL01 is also found inversely related with individual stock returns at $10 \%$ level. Drawing on our results, the positive effect of beta provides support to the Sharpe's CAPM which states that beta positively affects stock returns but our results also prove that beta is not the only variable influencing stock returns. The negative relationship of DFL is consistent with the results of Mandelker and Rhee (1984) which state that DFL and DOL have a tradeoff relationship related with firm's systematic risk; this negative relation can lead to negative relationship of DFL with stock returns. More specifically, this negative relation of DFL with stock returns is also consistent with results of Melicher (1974), which state that DFL has negative relationship with firms' stock returns and market risk. 
Considering results from the first model, we report that DOL has a significant and direct determining impact on stock returns while DFL is inversely associated with stock returns; however, the significance of DFL is not persistent. We also report that systematic risk $(\beta)$ and firm size (ME) are also found significantly predicting stock returns. The relationship of firm's size is consistent with Fama and French (1992), who report size of the firm and B/M ratio as significantly predicting stock returns. Empirical results from this section are consistent with the existing findings of García-Feijóo and Jorgensen (2010). In addition to this, our findings also provide support to theoretical views (Carlson et al. 2004; Cooper 2006; Zhang 2005; Berk et al. 1999) which state that value premium is the reward for risk relating to investment activity (operating leverage). It means that firms with higher $\mathrm{B} / \mathrm{M}$ ratios experience higher returns because these face higher systematic risk due to higher levels of operating leverage, thus suggesting direct association of operating leverage and stock returns.

Furthermore, a second empirical model is also estimated applying OLS technique, in which the $\mathrm{B} / \mathrm{M}$ ratio is regressed on DOL and DFL with the aim to analyze the impact of both leverages (DOL and DFL) on the $\mathrm{B} / \mathrm{M}$ ratio. Findings are reported below in Table 5, which clearly reveal that DOL is directly related to the $\mathrm{B} / \mathrm{M}$ ratio, while DFL is inversely related with $\mathrm{B} / \mathrm{M}$ ratio at $5 \%$ level of significance. For robustness, we also use alternative point-to-point measures of both DFL and DOL in this model. Findings reported in second column of Table 5, reveal that DOL01 is positively related with $\mathrm{B} / \mathrm{M}$ ratio at $5 \%$ significance level, while DFL01 is found to have negative and insignificant relationship. These findings also provide support to the theoretical notion that the $\mathrm{B} / \mathrm{M}$ effect is linked with the DOL. Contrarily, the negative coefficient of DFL is consistent with the results of our main $\mathrm{B} / \mathrm{M}$ ratio model given above, hence, proving that value effect is not the compensation of financial risk. This negative relationship of DFL with the $\mathrm{B} / \mathrm{M}$ ratio also inversely affects stock returns, consistent with the findings of Melicher (1974). Drawing on findings from this model, we report that DOL has direct association with $\mathrm{B} / \mathrm{M}$ ratio while DFL is found to have an inverse relationship with the $\mathrm{B} / \mathrm{M}$ ratio. These results also provide support to the findings from previous literature (García-Feijóo and Jorgensen 2010; Gulen et al. 2011). Additionally, these also support recent theoretical notions (Carlson et al. 2004; Cooper 2006; Zhang 2005; Berk et al. 1999), which state that value premium basically compensates for risk of investment activity (operating leverage), thus suggesting positive association of operating leverage with $\mathrm{B} / \mathrm{M}$ ratio.

Table 5. B/M Ratio regression results.

\begin{tabular}{ccccc}
\hline & \multicolumn{2}{c}{ Model 1: B/M Ratio } & \multicolumn{2}{c}{ Model 2: B/M Ratio } \\
\hline Variable & Coefficient & t-Statistics & Coefficient & t-Statistics \\
\hline & Panel A: Panel least square results (Fixed effect) \\
\hline Intercept & $-1.03^{* * *}$ & -86.06 & 0.22 & 0.26 \\
LNDOL & $0.033^{* *}$ & 2.41 & & \\
LNDFL & $-0.019^{* *}$ & -2.34 & $0.094^{* *}$ & 1.96 \\
LNDOL 01 & & & -0.26 & -1.40 \\
LNDFL & & & 0.15 \\
\hline Adj-R Square & & 0.86 & \multicolumn{3}{c}{} \\
\hline
\end{tabular}

Notes: This table examines the results from regressing firm Book to Market Ratio (B/M Ratio) on firm degree of operating leverage and degree of financial leverage. Values of $\mathrm{t}$-statistics are shown in the parentheses. ${ }^{* * *}$ and ${ }^{* *}$ indicate the coefficient is significant at $1 \%$ and $5 \%$ respectively.

At last, we also estimate the portfolio regression mode using the OLS technique on the basis of panel unit root testing. In this model systematic risks of portfolios are regressed on DOL and DFL of portfolios separately by controlling the size of portfolios. Results of this model are reported in Table 6; here again we find evidence in favor of risk relating to investment activity, and it is revealed that variable $D O L_{p}$ has a positive relationship with systematic risk of respective portfolios $\left(\beta_{p}\right)$ at $1 \%$ significance level, while $D F L_{p}$ is found to have negative and insignificant relationship with systematic risk of portfolios $\left(\beta_{p}\right)$. So once again, results are consistent with the findings of 
García-Feijóo and Jorgensen (2010). Therefore, we report that operating leverage has a direct influence on systematic risk $(\beta)$. This direct relation of DOL is also supported by the existing empirical studies (Darrat and Mukherjee 1995; Ho et al. 2004; Huffman 1983; Li and Henderson 1991; Lord 1996; Mandelker and Rhee 1984). On the other hand, the insignificant relationship of DFL with systematic risk is also consistent with a line of existing literature (Lord 1996; Darrat and Mukherjee 1995) which states that DFL has no relationship with systematic risk. In short, these results provide support to the recent theoretical opinion (Carlson et al. 2004; Cooper 2006; Zhang 2005; Berk et al. 1999), which suggest a positive relationship of DOL with systematic risk.

Table 6. Portfolio Systematic Risk regression results.

\begin{tabular}{|c|c|c|c|c|}
\hline \multirow[b]{2}{*}{ Variable } & \multicolumn{2}{|c|}{ Model 1: Beta $\left(\beta_{p}\right)$} & \multicolumn{2}{|c|}{ Model 2: Beta $\left(\beta_{p}\right)$} \\
\hline & Coefficient & t-Statistics & Coefficient & t-Statistics \\
\hline \multicolumn{5}{|c|}{ Panel A: Panel least square results (Random effect) } \\
\hline Intercept & $-1.60 * * *$ & -3.23 & $-1.16^{* * *}$ & -2.75 \\
\hline$L N D O L_{p}$ & $0.028 * * *$ & 2.67 & & \\
\hline$L N D F L_{p}$ & & & -0.02 & -1.15 \\
\hline$L N M E_{p}$ & $0.10^{* * *}$ & 4.76 & $0.09^{* * *}$ & 4.57 \\
\hline dj-R Squar & \multicolumn{2}{|c|}{0.16} & \multicolumn{2}{|c|}{0.16} \\
\hline
\end{tabular}

Notes: This table examines the results from regressing portfolio systematic risk $(\beta)$ on portfolio degree of operating leverage and degree of financial leverage. Values of $\mathrm{t}$-statistics are shown in the parentheses. ${ }^{* * *}$ indicates the coefficient is significant at $1 \%$.

Overall results of all three empirical models reveal that operating leverage has a significant and direct relationship with stock returns, $\mathrm{B} / \mathrm{M}$ ratio and market risk, respectively, whereas financial leverage is found to have an inconsistent association with all three. Drawing from these results, we accept our first hypothesis which states that operating leverage causes value premium. On the contrary, we observe no evidence in support of our second hypothesis, which states that financial leverage determines value premium. Consequently, our research reports that operating leverage derives value premium and provides support to the theoretical opinion that value premium compensates for the risk relating to the investment activity. According to this opinion, investment decisions are normally evaluated on the basis of real options, and options exercised can cause multiple variations in the firm's risk. For instance, if growth opportunities are limited, growth option to asset ratio changes as investment decision changes. In addition to this, it also results in increasing the physical capital which in turn increases the operating leverage through long term obligations such as commitments to suppliers, wage contracts, and fixed costs. Hence, it leads to the idea that high B/M firms face higher levels of risk due to investment decisions, thus these firms earn higher returns compared to their low $\mathrm{B} / \mathrm{M}$ counterparts. In short, this research provides support to the theoretical argument that high B/M firms face higher risk due to higher levels of DOL, and that is why these firms earn higher stock returns. Whereas, we do not observe evidence in support of the argument which relates financial distress risk with value effect. Finally, this research also finds that systematic risk (CAPM's beta) is not the only variable relating to firm's stock returns as operating leverage and firm's size are also found to have significant relationships with stock returns.

\section{Conclusions}

This research provides empirical evidence on the operating leverage hypothesis theorized by the recent line of study (Cooper 2006; Zhang 2005; Carlson et al. 2004; Berk et al. 1999), claiming operating leverage as the major determinant of value premium. Researchers have developed contradictory theoretical opinions regarding the risk-based nature of value premium. It is still inconclusive whether value premium is the compensation for the risk relating to investment activity or compensation for the financial distress risk. This paper incorporates DOL and DFL to compare both theoretical opinions on how operating leverage and financial leverage determine the value premium. To estimate DOL 
and DFL, a time series regression method given by Mandelker and Rhee (1984) is applied whereas alternative point-to-point measures are also included in the analysis for robust testing. Panel data regression analysis reports clear evidence on the impact of operating leverage (DOL) on the stock returns, $\mathrm{B} / \mathrm{M}$ ratio and market risk respectively while financial leverage (DFL) is found to have insignificant association with value premium. In addition to this, systematic risk (beta) and market size are also found to be significantly affecting the stock returns. Drawing on the results, we provide support for theoretical opinion featuring operating leverage as the major determining factor behind value premium (Carlson et al. 2004; Cooper 2006; Zhang 2005; Berk et al. 1999). Our results are consistent to the previous empirical findings of the García-Feijóo and Jorgensen (2010). Contrarily, we report no empirical evidence for the theories suggesting financial leverage as the determinant of value premium (Ozdagli 2012; Obreja 2013). Overall, our findings suggest that DOL is the main driving factor causing the value premium in the nonfinancial sector of Pakistan. It implies that high B/M firms face higher risk due to higher level of operating leverage, and, therefore, these firms earn higher returns.

In the case of Pakistan, existing literature has tested different asset pricing models and reports the existence of value premium (Shah and Amir 2017; Hassan and Javed 2011). However, there is a lack of empirical research on the factors determining value premium. Considering this, our research is an effort to fill this gap and contributes to the existing literature by providing significant empirical evidence on the operating leverage as a determining factor of value premium in the context of the Pakistan stock exchange.

The findings of this research have various risk-based implications. Our results implicate that stock investors in Pakistan should invest in value stocks (high B/M ratio) with high investment activity risk in order to beat the market. These investors are also advised not to invest in growth (low B/M ratio) stocks because these stocks in Pakistan do not have much potential to give higher returns. Furthermore, investors are also advised not to focus much on financial distress risk of the firms because it has weak significance and an inconsistent association with the stock returns. Finally, we also suggest the shareholders and senior management of the firms focus on investment activity risk (operating leverage) in order to control market demand of their stocks.

This study has few limitations, which also indicate future research directions. Major limitations of this research lie in the measurement of both operating and financial leverages. Considering the complexity associated with the measurement of both variables, future studies should try more alternative proxies for achieving better outcomes. There are also chances of "error in variable" problems in estimating both leverages, which can be addressed by employing advanced methods of an instrumental technique or portfolio approach in future empirical assessments. In addition to this, our study also lacks in providing empirical evidence for different sectors. Therefore, future studies may also incorporate industrial level analysis.

Author Contributions: Conceptualization, H.M.Z.u.h. and M.S.S.; methodology, data curation and formal analysis, M.K. and H.M.Z.u.h.; writing—original draft preparation, H.M.Z.u.h. and M.S.S.; writing-review and editing, S.A.; All authors have read and agreed to the published version of the manuscript.

Funding: This research received no external funding.

Acknowledgments: The authors are grateful to anonymous MDPI referees and editors.

Conflicts of Interest: The authors declare no conflict of interest.

\section{References}

Berk, Jonathan B., Richard C. Green, and Vasant Naik. 1999. Optimal investment, growth options, and security returns. The Journal of Finance 54: 1553-607. [CrossRef]

Bowman, Robert G. 1979. The theoretical relationship between systematic risk and financial (accounting) variables. The Journal of Finance 34: 617-30. [CrossRef]

Campbell, John Y., Jens Hilscher, and Jan Szilagyi. 2008. In search of distress risk. The Journal of Finance 63: 2899-939. [CrossRef] 
Cao, Viet Nga. 2015. What explains the value premium? The case of adjustment costs, operating leverage and financial leverage. Journal of Banking \& Finance 59: 350-66.

Carlson, Murray, Adlai Fisher, and Ron Giammarino. 2004. Corporate Investment and Asset Price Dynamics: Implications for the Cross-section of Returns. The Journal of Finance 59: 2577-603. [CrossRef]

Chen, Nai-fu, and Feng Zhang. 1998. Risk and Return of Value Stocks. The Journal of Business 71: 501-35. [CrossRef]

Cooper, Ilan. 2006. Asset pricing implications of nonconvex adjustment costs and irreversibility of investment. The Journal of Finance 61: 139-70. [CrossRef]

Daniel, Kent, and Sheridan Titman. 1997. Evidence on the characteristics of cross sectional variation in stock returns. The Journal of Finance 52: 1-33. [CrossRef]

Darrat, Ali F., and Tarun K. Mukherjee. 1995. Inter-industry differences and the impact of operating and financial leverages on equity risk. Review of Financial Economics 4: 141-55. [CrossRef]

Fama, Eugene F., and Kenneth R. French. 1992. The cross-section of expected stock returns. The Journal of Finance 47: 427-65. [CrossRef]

Fama, Eugene F., and Kenneth R. French. 1993. Common risk factors in the returns on stocks and bonds. Journal of Financial Economics 33: 3-56. [CrossRef]

Fama, Eugene F., and Kenneth R. French. 1995. Size and book-to-market factors in earnings and returns. The Journal of Finance 50: 131-55. [CrossRef]

Fama, Eugene F., and Kenneth R. French. 1996. Multifactor explanations of asset pricing anomalies. The Journal of Finance 51: 55-84. [CrossRef]

Fama, Eugene F., and Kenneth R. French. 2015. A five-factor asset pricing model. Journal of Financial Economics 116: 1-22. [CrossRef]

Fama, Eugene F., and James D. MacBeth. 1973. Risk, return, and equilibrium: Empirical tests. The Journal of Political Economy 81: 607-36. [CrossRef]

Fong, Wai Mun. 2012. Do expected business conditions explain the value premium? Journal of Financial Markets 15: 181-206. [CrossRef]

García-Feijóo, Luis, and Randy D. Jorgensen. 2010. Can operating leverage be the cause of the value premium? Financial Management 39: 1127-54. [CrossRef]

Gulen, Huseyin, Yuhang Xing, and Lu Zhang. 2011. Value versus Growth: Time-Varying Expected Stock Returns. Financial Management 40: 381-407. [CrossRef]

Guthrie, Graeme. 2013. A value premium without operating leverage. Finance Research Letters 10: 1-11. [CrossRef]

Hamada, Robert S. 1972. The effect of the firm's capital structure on the systematic risk of common stocks. The Journal of Finance 27: 435-52. [CrossRef]

Hassan, Arshad, and Muhammad Tariq Javed. 2011. Size and value premium in Pakistani equity market. African Journal of Business Management 5: 6747-55.

Hausman, Jerry A. 1978. Specification tests in econometrics. Econometrica: Journal of the Econometric Society 1: 1251-71. [CrossRef]

Ho, Yew Kee, Zhenyu Xu, and Chee Meng Yap. 2004. R\&D investment and systematic risk. AccountingE Finance 44: 393-418.

Hou, Kewei, Chen Xue, and Lu Zhang. 2015. Digesting anomalies: An investment approach. The Review of Financial Studies 28: 650-705. [CrossRef]

Huffman, Lucy. 1983. Operating leverage, financial leverage, and equity risk. Journal of Banking $\mathcal{E}$ Finance 7: 197-212.

Iqbal, Javed, and Robert Brooks. 2007. Alternative beta risk estimators and asset pricing tests in emerging markets: The case of Pakistan. Journal of Multinational Financial Management 17: 75-93. [CrossRef]

Javid, Attiya Yasmin. 2009. Test of higher moment capital asset pricing model in case of Pakistani equity market. European Journal of Economics, Finance and Administrative Studies 15: 144-62.

Javid, Attiya Y., and Eatzaz Ahmed. 2008. The Conditional Capital Asset Pricing Model: Evidence from Karachi Stock Exchange. Islamabad: Pakistan Institute of Development Economics, vol. 48.

Khan, Faisal, Shahid Ali, and Arshad Hassan. 2012. Size, leverage and stocks returns: Evidence from Pakistan. International Journal of Academic Research 4: 24-33.

Lakonishok, Josef, Andrei Shleifer, and Robert W. Vishny. 1994. Contrarian investment, extrapolation, and risk. The Journal of Finance 49: 1541-78. [CrossRef] 
Lev, Baruch. 1974. On the association between operating leverage and risk. Journal of Financial and Quantitative Analysis 9: 627-41. [CrossRef]

Levin, Andrew, Chien-Fu Lin, and Chia-Shang James Chu. 2002. Unit root tests in panel data: Asymptotic and finite-sample properties. Journal of Econometrics 108: 1-24. [CrossRef]

Li, Rong-Jen, and Glenn V. Henderson Jr. 1991. Combined leverage and stock risk. Quarterly Journal of Business and Economics 30: 18-39.

Light, Nathaniel, Denys Maslov, and Oleg Rytchkov. 2017. Aggregation of information about the cross section of stock returns: A latent variable approach. The Review of Financial Studies 30: 1339-81. [CrossRef]

Ljungqvist, Alexander, and William J. Wilhelm Jr. 2005. Does prospect theory explain IPO market behavior? The Journal of Finance 60: 1759-90. [CrossRef]

Lord, Richard A. 1996. The impact of operating and financial risk on equity risk. Journal of Economics and Finance 20: 27-38. [CrossRef]

Mandelker, Gershon N., and S. Ghon Rhee. 1984. The impact of the degrees of operating and financial leverage on systematic risk of common stock. Journal of Financial and Quantitative Analysis 19: 45-57. [CrossRef]

McLean, R. David, and Jeffrey Pontiff. 2016. Does academic research destroy stock return predictability? The Journal of Finance 71: 5-32. [CrossRef]

Melicher, Ronald W. 1974. Financial factors which influence beta variations within an homogeneous industry environment. Journal of Financial and Quantitative Analysis 9: 231-41. [CrossRef]

Mirza, Nawazish, and Saima Shahid. 2008. Size and Value Premium in Karachi Stock Exchange. Lahore Journal of Economics 13: 1-26. [CrossRef]

Modigliani, Franco, and Merton H. Miller. 1958. The cost of capital, corporation finance and the theory of investment. The American Economic Review 48: 261-97.

Modigliani, Franco, and Merton H. Miller. 1963. Corporate income taxes and the cost of capital: A correction. The American Economic Review 53: 433-43.

Novy-Marx, Robert. 2011. Operating Leverage. Review of Finance 15: 103-34. [CrossRef]

Obreja, Iulian. 2013. Book-to-market equity, financial leverage, and the cross-section of stock returns. The Review of Financial Studies 26: 1146-89. [CrossRef]

Ozdagli, Ali K. 2012. Financial leverage, corporate investment, and stock returns. The Review of Financial Studies 25: 1033-69. [CrossRef]

Rubinstein, Mark E. 1973. A mean-variance synthesis of corporate financial theory. The Journal of Finance 28: 167-81. [CrossRef]

Shah, Tanveer Ahmad, and Syed Muhammad Amir. 2017. The Value-Growth Indicators and Value Premium: Evidence from Pakistan Stock Exchange. South Asian Journal of Management Sciences (SAJMS), Iqra University 11: 124-39.

Sharpe, William F. 1964. Capital asset prices: A theory of market equilibrium under conditions of risk. The Journal of Finance 19: 425-42.

Wu, Mengyun, Muhammad Imran, Yanhua Feng, Linrong Zhang, and Muhammad Abbas. 2017. Review and validity of capital asset pricing model: Evidence from Pakistan stock exchange. International Research in Economics and Finance 1: 21. [CrossRef]

Zhang, Lu. 2005. The value premium. The Journal of Finance 60: 67-103. [CrossRef]

(C) 2020 by the authors. Licensee MDPI, Basel, Switzerland. This article is an open access article distributed under the terms and conditions of the Creative Commons Attribution (CC BY) license (http://creativecommons.org/licenses/by/4.0/). 